\title{
COMPARATIVE TROPES AS A MEANS OF AXIOLOGICAL MEDIA CONTEXT FORMATION
}

\begin{abstract}
The article is devoted to the establishment of the role of the axiological potential of comparative tropes in the formation of the axiological context of a publicistic sketch. A separate axiological context is characterized by a certain degree of axiological tension, which is determined by the amount and intensity of the evaluation means used in it. Stylistic means based on comparison are characterized by brightness of images, expressive and emotive components, which result in the creation of a highly-intensive evaluation at the functioning of tropeic explications in the context. The language of the journalistic style is rich and vivid, in some cases it has imagery and estimation, which is a consequence of the realization of such functions of the mass media as commentary-evaluative and manipulative. Publicistic sketch has characteristics of artistic and journalistic style, in connection with which in most cases it is featured by high axiological tension and relief author's images. In this publication the author considers evaluative contexts, whose evaluation is created mainly due to the use of author's comparative figures, at the level of the evaluation context and evaluative statements, singled out in the text of one journalistic sketch with the aim of analyzing a separate axiological context as a whole.
\end{abstract}

Keywords: comparative tropes, axiological tension, degree of axiological tension, axiological potential, axiological context, publicistic sketch, evaluation.

\section{О.Б. Солдатова}

Барнаульский юридический институт МВД России, Барнаул, Российская Федерация
Получена: 28.08.2017

Принята: 10.09.2017

Опубликована: 30.09.2017

\section{КОМПАРАТИВНЫЕ ТРОПЫ КАК СРЕДСТВО СОЗДАНИЯ АКСИОЛОГИЧЕСКОГО МЕДИАКОНТЕКСТА}

\footnotetext{
Статья посвящена вопросу роли аксиологического потенциала компаративных тропов в формировании аксиологического контекста публицистического очерка. Отдельный аксиологический контекст характеризуется определенной степенью аксиологической нагруженности, которая детерминирована количеством и интенсивностью используемых в нем оценочных средств. Стилистические средства, основанные на сравнении, характеризуются яркостью образов, экспрессивной и эмотивной составляющей, что имеет результатом создание высокоинтенсивной оценки при функционировании тропеических экспликаций в контексте. Язык публицистического стиля богат и вариативен, в ряде случаев обладает образностью и оценочностью, что является следствием реализации таких функций средств массовой информации, как комментарийно-оценочная и манипулятивная. Публицистический очерк имеет характеристики художественного и публицистического стиля, в связи с чем в большинстве случаев отличается высокой аксиологической нагруженностью и рельефностью авторских образов. В данной публикации автор рассматривает оценочные контексты, оценка которых создается главным образом за счет использования авторских компаративных тропов на уровне оценочных контекстов и оценочных высказываний, выделяемых в тексте одного публицистического очерка с целью анализа отдельного аксиологического контекста как единого целого.

Ключевые слова: компаративные тропы, аксиологическая нагруженность, степень аксиологической нагруженности, аксиологический потенциал, аксиологический контекст, публицистический очерк, оценка.
} 
Human life is closely connected with evaluation based on the process of comparing received information about the surrounding reality with already existing knowledge, empirical experience, social and individual values. In gnosiology, the evaluation is presented as a complex form of cognition, the subject's ability to reflect the phenomena of the surrounding reality in the consciousness, in particular from the point of view of their significance for human activity [1]. Taking into account the existence of a multilateral description of the notion of evaluation and a large number of approaches to the problem of its functioning and formation, it is necessary to emphasize its categorical status. Within the framework of linguistics, categorization is the process of forming and separating the categories themselves from analogous essential characteristics or properties similar to those found in the analyzed phenomena [2]. The category of evaluation, being not conceivable in a language without a subject evaluating the world, is one of anthropological categories that are conceptual in nature [3].

The evaluation is reflected in the language and speech, including journalism discourse. The language of the media is rich and varied, due to the need to draw the attention of the reader to particular nuances of the situation, to express the author's attitude to the event or to comment on what is happening, to form the recipient's attitude to the covered events, to present the context of entertainment and make the text memorable, interesting and informative. These peculiarities are the result of the media text's functions. A.N. Baranov and V.V. Parshin single out the following functions of the modern press: informational, commentary-evaluative, cognitive-educational, function of influence and formation of public opinion, hedonistic (information delivery in a way that meets the aesthetic needs of the recipient) and entertaining [4]. Such functions as commentary-evaluation, impact and formation of public opinion, hedonistic and entertaining are often realized by evaluative contextual means.

Contextually evaluation can be represented in various ways: created by lexical, grammatical, stylistic, syntactic, graphic and phonetic means; have complex or occasional nature; be explicit or implicit. A nalyzing a particular journalistic text, the authors of which not only inform the reader, but express their attitude to what is happening, assess the situation, it is reasonable to speak about the axiological context. A ccording to the proposed interpretation of V.A. M arjanchik the axiological context is a totality of value concepts and evaluations that are explicated or implied in the text, and are also recreated in consciousness as a result of the actualization of personal experience [5].

A separate text can be characterized by a different degree of axiological tension, which is dictated in particular by the genre characteristics of the texts; thus, the informational genre of the journalistic style is almost devoid of appraisal and is aimed directly at covering facts and events of the life of the society and the international community, which determines the low degree or absence of axiological tension in the text ; the analytical genre is characterized by the presence of an average and high degree of 
axiological tension, since the main task of a journalist in this type of text is to express an attitude about the presented facts; the artistic and journalistic texts of the press have high axiological indicators, since the genres of this group of journalistic style (feuilleton, sketch, pamphlet, parody, etc.) are characterized by emotionality, imagery and stylistic means saturation. The degree of axiological tension is estimated on the basis of character and quantitative indicators of axiological means, intensity, emotiveness and volume of imagery tropes, used to create and express evaluation in a separate context. This article is to consider the axiological context of sketch "Tony Blair Told Princess Diana her Relation with Dody Fayed was a Problem" by A. Hill. The sketch is a short narrative work, the main purpose of which is a figurative illustration or imaginative information, unlike the informative and analytical genres it absorbs the signs of two spheres: artistic speech and journalism [6]. As it becomes obvious from the definition, the axiological tension in the texts of this type is high, which is due to the complex character of used evaluation means. Comparative tropes can play the role of language evaluation explications in particular, representing cases of secondary nomination. Stylistic means, based on comparison, indicating the similarity of one object to another, regardless of whether it is permanent or transient, valid or apparent [7], are characterized by imagery, high emotional load and a large volume of conceptual content. In cases of expressing evaluation in the text with the help of trope explications, evaluation is inherently expressive and emotive.

The theoretical basis for this study are works in the sphere of axiological linguistics $[5,8]$, medialinguistics $[9,10,11,12]$ and functional stylistics $[13,14]$. The analysis of stylistic means is covered in a large amount of works, which are predominantly based on such fundamental theories as the cognitive theory of the metaphor by J. L akoff and M. Johnson [15] and the conceptual integration of mental spaces by M. Turner and J. Fauconnier [16]. A number of studies are currently aimed at identifying pragmatic features of the stylistic means functioning in the publicistic style $[17,18,19]$.

The material for this study is presented by more than 5,000 appraisal contexts of the B ritish newspaper The Guardian, whose axiological character is determined by the use of comparative stylistic means. The main theory covered in this article is the statement that author's comparative figures (tropes), which have brightness of images and artistic expressiveness, are one of the main means of forming an axiological context, due to the high degree of axiological potential, that is a high degree of the probability of creating an intense emotional evaluation in the text. In the process of the material analysis the author used the method of scientific modeling, conceptual analysis, methods of semantic, lexical, contextual and stylistic analysis.

When considering an evaluation at the context level L.Y u. Ivanov proposes the following hierarchy of appraisal units: evaluative macrotext (text) - evaluative context (unit of text) - evaluative sentence - evaluative quantum (word or phrase in a certain syntactic position, elementary evaluation unit) - evaluative word (unit of 
lexical system) - evaluative morpheme or grapheme [20, p. 77]. Within the framework of this publication, we will consider evaluative contexts, whose evaluation is created mainly due to the use of author's comparative figures, at the level of the evaluation context and evaluative statements, singled out in the text of one journalistic sketch [21] with the aim of analyzing a separate axiological context as a whole:

(1) "We were both in our ways manipulative people," Blair writes, "perceiving quickly the emotions of others and able instinctively to play with them."

The given axiological context is characterized by a low degree of axiological tension due to the fact that the nature of the evaluation is implicit. This microcontext can be described as pejorative, because the definition of the lexeme manipulative 'someone who is manipulative makes people do what they want by influencing them in a clever or dishonest way' is marked showing disapproval, respectively, there is an explicit negative content on the level of the word meaning. The worn metaphor play with, used to indicate the ability of Princess Diana and Tony Blair to manage and drive people also implies a negative evaluation. At the same time, the author's use of the negative assessment in respect to themselves is a way to deintensify it because in politics and the country management these are indispensable qualities of a leader.

(2) As well as admitting a strong personal fondness for Princess Diana - "I really liked her and, of course, was as big a sucker for a beautiful princess as the next man; but I was wary too" - Blair saw her as encapsulating the political sea change that swept the country in 1997: "Whatever New Labour had in part," Blair writes, "she had in whole".

Comparison as big as a sucker for a beautiful princess as the next man is a comparative trope based on the interaction of the concepts sucker and close person, where the semantic blends are the implications "constant communication", "dependence", "common interests". B ringing this stylistic means in the context of direct quoting of $\mathrm{T}$. B lair's words translates information of close communication, almost family relations between him and the princess, however, the prime minister should be cautious and attentive. The metaphorical presentation of the conceptual process encapsulating the political sea that swept the country in 1997 creates a voluminous, relief image of Diana's perspicacious perception of events, which consists of several separate metaphors. Thus, the trope explication of encapsulating is in relation to the nomination understand the whole thing with the semantic blends "unite", "visibility", "picture of events", "to understand all the nuances". The metaphor the political sea change evokes the image of a huge sea wave, where the semantic blends are "squall", "impossibility to resist and avoid a collision", "universal coverage", the scope of change is also explicated by the verbal nomination swept the country. Prudence of Princess Diana is rep- 
resented in the author's opposition "Whatever New Labor had in part," Blair writes, "she had in whole". The used stylistic means create a relief verbal image of the extraordinary personality of the princess, charming, beautiful, intelligent, able to view the whole political situation in the country, which reveals T. Blair's positive evaluation of Diana's personal features at the level of this axiological microcontext. In addition to stylistic means, the meliorative axiological context is created due to the functioning of positively evaluative lexical means: $a$ strong personal fondness, really liked. Thus, all the used evaluative means determine the high degree of the axiological tension in the given context.

(3) But Diana was, writes Blair, "an unpredictable meteor" who burst into the royal family's "predictable and highly regulated ecosystem".

The analyzed microcontext is almost completely inwrought with stylistic means, the purpose of which is the explication of a complex metaphor of the conceptual process. The metaphorisation of Princess Diana's personality, nominated as "an unpredictable meteor", implicates semes "energy", "quickness", "independence", "extraordinary", "brightness". The process of entering the royal family is represented by the nomination burst, which determines the creation of images of a collision and explosion, caused by the difference in mentality and personal characteristics of members of the host family and the princess. The metaphorical presentation of the royal family "predictable and highly regulated ecosystem" creates an image of a measured, honorable life that is devoid of vivid emotions and unplanned situations. Of particular note is the anthonymic nature of the used epithets unpredictable / predictable and highly regulated. All of the above-mentioned comparative tropes are used to build a strong metaphorical image - the appearance of Diana in the Windsor house was similar to the collision of a meteor with an inhabited planet, the consequences of which cannot be evaluated positively. Accordingly, the analyzed example is a pejorative axiological microcontext. The use of quotation marks is a way to focus the attention of the recipient on the information contained in them, therefore, it can be argued that quotes are a graphical way to intensify the evaluation of this sentence. All the mentioned means of evaluation result in high degree of axiological tension of the context.

(4) Diana didn't like Blair's interference - "I could feel the willful side of her bridling" - but by the end of the conversation they were again on a "warm and friendly" footing.

M etaphor the willful side of her bridling is in relation to the concept the behavior of a fractious horse with semantic blends "unruly", "freedom-loving", "freethinking", "independence", which creates the image of Diana as a person ready to defend her opinion, to disobey, nevertheless, T. Blair, as a great diplomat, could find a common language with her - they were again on a "warm and friendly" footing. The sign of the evaluation of this axiological context, as well as of this publicistic sketch on the whole, is ambivalent - T. Blair positively estimates the personality of the 
princess, he treats her warmly, but as a politician he evaluates her negatively regarding her rampant, boiling passions, incontinence and freethinking, which is absolutely unacceptable for the W indsor house and for political affairs. The analyzed microcontext is characterized by the middle axiological tension degree.

(5) Blair is candid about the tension of the days immediately following Diana's death: "Throughout, we were walking a tightrope, thinner and more frayed by the day, between organising everything to go well and 'cashing in' or exploiting."

The British Prime M inister uses a relief verbal image to present the political situation after the death of Princess Diana, comparing it with walking on a rope, where tightrope 'a piece of rope or wire high above the ground that a performer walks along in a circus'. The analyzed metaphor interacts with the nomination to be in a difficult situation, where the semantic blends are "danger", "fatality of an error", "impossibility to turn back". Every day the situation became more and more difficult (thinner and more frayed by the day). The unfolding of the figurative line and the comparison of the situation complication with a thinning old rope of poor quality leads to an intensification of the negative evaluation of the prevailing state of things, in which it was necessary to think carefully about each step and every word. The pejorative nature of this axiological microcontext is mostly determined by the functioning of the comparative tropes in it. However, we should also underline the role of lexical (the lexemes tension, death are characterized by the presence of a strong axiological potential) and grammatical (the comparative degree of adjectives thinner and more frayed, the use of the form Past Continuous were walking, which emphasizes the duration and process of this state) means of evaluation expression. Taking into consideration all the functioning evaluative means it is necessary to underline that the axiological tension of the given microcontext is extremely high.

On the basis of the material analysis, using this publicistic sketch as a verifying example, the following conclusions can be drawn: 1. the axiological context is created by the integrated use of means of expressing an evaluation: lexical means (in most cases inherently evaluative and implicitly evaluative lexemes), grammatical (passive voice, comparative degree of adjectives, verb tenses), graphic (quotes, font change) and stylistic (artistic figurative stylistic means); 2. author's comparative tropes, characterized by emotiveness and expressiveness, have a high axiological potential when functioning in a journalistic text and are one of the main means of creating an axiological context; 3 . the degree of axiological tension of the text is determined by the intensity of the axiological potential of individual means and the number of evaluation representatives used in the context; 4 . the degree of axiological tension of the text is determined by the style and genre to which it belongs, a publicistic sketch, as an artistic and journalistic genre of journalistic style, is characterized by a high degree of axiological tension due to imagery, artistic author's presentation of information. 
Comparative paths are a powerful source of indirect influence and manipulation in the political texts of the British press due to the creation of original, vivid imagery and the implication of evaluation associations. Studying the peculiarities of the language of the mass media in modern linguistics makes it possible to analyze the pragmatic potential of linguistic means in the sphere of modeling the opinion of the population and influencing the public picture of the world.

\section{References}

1. Granin Iu.D. 0 gnoseologicheskom soderzhanii poniatiia "otsenka" [On the epistemological content of the concept of "evaluation"]. V filosofii, 1987, no. 6, pp. 75-98.

2. Kubriakova E.S. Iazyk i znanie: $N$ a puti polucheniia znanii o iazyke: Chasti rechi $s$ kognitivnoi tochki zreniia. Rol' iazyka v poznanii mira [Language and knowledge: On the way of getting knowledge about the language: Parts of speech from the cognitive point of view. The role of language in the knowledge of the world]. M oscow, 2004.

3. Trunova O.V. Priroda i iazykovoi status kategorii modal'nosti (na materiale angliiskogo iazyka) [The nature and language status of the modality category (on the material of the English language)]. Barnaul, Novosibirsk, Izdatel'stvo B arnaul'skogo gosudarstvennogo pedagogicheskogo universiteta, 1991.

4. Baranov A .N., Parshin V.V. Iazykovye mekhanizmy variativnoi interpretatsii deistvitel'nosti kak sredstvo vozdeistviia na soznanie [Language mechanisms of the variable interpretation of reality as a means of influencing the mind]. Rol' iazyka $v$ sredstvakh massovoi informatsii, 1986, pp. 100-143.

5. M ar'ianchik V.A. A ksiologicheskaia struktura media-politicheskogo teksta (lingvostilisticheskii aspekt) [The axiological structure of the media-political text (linguostylistic aspect)]. A bstract of Doctor's degree dissertation. A rkhangelsk, 2013.

6. Sycheva E.V. K hudozhestvenno-publitsisticheskaia raznovidnost' diskursa massmedia (na materiale ocherka V. Peskova "V upriazhke zhizni") [An artistic-journalistic version of the discourse of the mass media (based on the sketch by V. Peskov "In the harness of life")]. Iazyk. Tekst. Diskurs, 2011, no. 9, pp. 351-357.

7. A rutiunova N.D. Iazyk i mir cheloveka [Language and human world]. M oscow, 1999.

8. Ivin A.A. Otsenka v protsessakh kommunikatsii [Evaluation in the communication processes]. Filosofiia nauki i tekhniki, 2012, vol. 17, no. 1, pp. 203-213.

9. Solganik G.Ia. K opredeleniiu poniatii "tekst" i "mediatekst" [On defining the concepts "text" and "mediatext"]. Vestnik Moskovskogo universiteta. Ser. 10: Zhurnalistika, 2005, no. 2, pp. 7-16.

10. B obkov A .K. Gazetnye zhanry [N ewspaper genres]. Irkutsk, 2005.

11. Annenkova I.V. Sovremennaia mediakartina mira: neoritoricheskaia model' [M odern media picture of the world: Neoretorical model]. A bstract of Doctor's degree dissertation. M oscow, 2012.

12. Shmeleva T.V. M ediatizatsiia kak fenomen sovremennoi kul'tury i ob"ekt issledovaniia [M ediatization as a phenomenon of modern culture and the object of research]. Vestnik Novgorodskogo gosudarstvennogo universiteta im. Iaroslava Mudrogo, 2015, no. 7(90), pp. 145-148. 
13. A rnol'd I.V. Stilistika. Sovremennyi angliiskii iazyk [Stylistics. Modern English language]. M oscow, 2010.

14. K lushina N.I. Diskurs-analiz i stilistika: integrativnye metody issledovaniia media kommunikatsii [Discourse analysis and stylistics: Integrative methods of media communication research]. Vestnik Rossiiskogo universiteta druzhby narodov. Seriia: Lingvistika, 2016, vol. 20, no. 4, pp. 78-90.

15. Lakoff G., Johnson M. M etaphors we live by. Chicago, The U niversity of Chicago Press, 1980, 276 p. [Russ. ed.: Lakoff Dzh., Dzhonson M. Metafory, kotorymi my zhivem. Ed. by A.N. Baranov. M oscow, Editorial URSS, 2004, 256 p.].

16. Fauconnier G., Turner M. Conceptual projection and middle spaces. A vailable at: http://www.cogsci.ucsd.edu/research/documents/technical/9401.pdf (accessed 20 A ugust 2017).

17. Chudinov A.P. Sovremennaia politicheskaia lingvistika [Modern political linguistics]. Ekaterinburg, 2011.

18. Bezzubov A.N. Stilisticheskie priemy gazetnoi rechi [Stylistic devices of newspaper speech]. Saint-Petersburg, 2000.

19. Zheltukhina M.R. Tropologicheskaia suggestivnost' mass-medial'nogo diskursa: o probleme rechevogo vozdeistviia tropov v iazyke SMI [Tropologic suggestibility of mass-media discourse: On the problem of speech influence of tropes in the language of the media]. Moscow, 2003.

20. Ivanov L.Iu. Tekst nauchnoi diskussii: deiksis i otsenka [The text of the scientific discussion: Deixis and evaluation]. M oscow, 2003.

21. Hill A. Tony Blair told Princess Diana her relationship with Dodi Fayed was a problem. A vailable at: https://www.theguardian.com/politics/2010/sep/01/tony-blair-dianarelationship-fayed (accessed 20 A ugust 2017).

\section{Список литературы}

1. Гранин Ю.Д. О гносеологическом содержании понятия «оценка» // В философии. - 1987. - №6. - С. 75-98.

2. Кубрякова Е.С. Язык и знание: На пути получения знаний о языке: Части речи с когнитивной точки зрения. Роль языка в познании мира. - М., 2004.

3. Трунова О.В. Природа и языковой статус категории модальности (на материале английского языка). - Барнаул; Новосибирск: Изд-во БГПУ, 1991.

4. Баранов А.Н., Паршин В.В. Языковые механизмы вариативной интерпретации действительности как средство воздействия на сознание // Роль языка в средствах массовой информации. - 1986. - С. 100-143.

5. Марьянчик В.А. Аксиологическая структура медиа-политического текста (лингвостилистический аспект): автореф. дис. ... д-ра наук. - Архангельск, 2013.

6. Сычева Е.В. Художественно-публицистическая разновидность дискурса масс-медиа (на материале очерка В. Пескова «В упряжке жизни») // Язык. Текст. Дискурс. - 2011. - № 9. - С. 351-357.

7. Арутюнова Н.Д. Язык и мир человека. - М., 1999.

8. Ивин А.А. Оценка в процессах коммуникации // Философия науки и техники. - 2012. - Т. 17, №1. - С. 203-213.

9. Солганик Г.Я. К определению понятий «текст» и «медиатекст» // Вестник Моск. ун-та. Сер. 10: Журналистика. - 2005. - № 2. - С. 7-16. 
10. Бобков А.К. Газетные жанры. - Иркутск, 2005.

11. Анненкова И.В. Современная медиакартина мира: неориторическая модель: автореф. дис. ... д-ра филол. наук. - М., 2012.

12. Шмелева Т.В. Медиатизация как феномен современной культуры и объект исследования // Вестник Новгород. гос. ун-та им. Ярослава Мудрого. - 2015. - №7 (90). C. $145-148$.

13. Арнольд И.В. Стилистика. Современный английский язык. - М., 2010.

14. Клушина Н.И. Дискурс-анализ и стилистика: интегративные методы исследования медиа коммуникации // Вестник Рос. ун-та дружбы народов. Сер. Лингвистка. - 2016. - Т. 20. - № 4. - С. 78-90.

15. Лакофф Д., Джонсон М. Метафоры, которыми мы живем. - М., 2008.

16. Fauconnier G., Turner M. Conceptual Projection and M iddle Spaces [Электронный ресурc]. - URL: http://www.cogsci.ucsd.edu/research/documents/technical/9401.pdf (дата обращения: 20.08.2017).

17. Чудинов А.П. Современная политическая лингвистика. - Екатеринбург, 2011.

18. Беззубов А.Н. Стилистические приемы газетной речи. - СПб., 2000.

19. Желтухина М.Р. Тропологическая суггестивность масс-медиального дискурса: о проблеме речевого воздействия тропов в языке СМИ. - М., 2003.

20. Иванов Л.Ю. Текст научной дискуссии: дейксис и оценка. - М., 2003.

21. Hill A. Tony Blair told Princess Diana her relationship with Dodi Fayed was a problem [Электронный ресурc]. - URL: https://www.theguardian.com/politics/2010/sep/01/tonyblair-diana-relationship-fayed (дата обращения: 20.08.2017).

\section{Сведения об авторе}

\section{СОЛДАТОВА Олеся Борисовна}

e-mail: bugaeva82@mail.ru

Кандидат филологических наук, научный сотрудник научно-исследовательского и редакционно-издательского отдела, Барнаульский юридический институт МВД России (Барнаул, Российская Федерация)

\section{About the author}

\section{Olesya B. SOLDATOVA}

e-mail: bugaeva82@mail.ru

Candidate of Philological Sciences, Researcher, Research and Editorial-Publishing Department, B arnaul Law Institute of the M inistry of Internal A ffairs of Russia (Barnaul, Russian Federation) 